\title{
IMPLEMENTATION OF ENERGY EFFICIENT PRINCIPLES IN MANAGEMENT OF AN APARTMENT BUILDING IN UKRAINE
}

\author{
Stanislav Kiris ${ }^{1}$
}

\begin{abstract}
The purpose of this article is to analyze the efficiency of management of an apartment building in the context of energy efficiency. The article describes the conduct of an energy audit for apartment buildings, which allows a thorough assessment of this problem and identify optimal ways to save energy resources by apartment buildings. Energy audit is a special examination of residential buildings or enterprises, conducted by specialized specialists in energy certification of buildings to determine their technical condition and energy efficiency. Methodology. Within the framework of this article, the results of a sociological survey conducted among the heads of condominiums to analyze the level of their interest in the implementation of energy efficiency measures were analyzed. The value of the cost of 1 apartment for the implementation of the energy modernization project is calculated. Currently, "energy efficiency" and "energy saving" are extremely popular in Ukraine, due to the following: increasing the cost of energy resources;limited financial capacity of vulnerable groups to pay for services. Results of the survey showed an insufficient level of implementation of energy-saving technologies, although the level of interest of apartment building heads is very high. The development of energy efficiency programs for an apartment building is carried out not only taking into account the necessary priority measures, but also based on the financial capacity of the co-owners of the apartment building. The reason for the insufficient implementation of energy saving measures is the insufficient financial capacity of co-owners and, as a consequence, the apartment buildings themselves. State support for the implementation of energy efficiency in the management of apartment buildings has been studied in detail. It is concluded that large-scale involvement of apartment buildings in the implementation of energy efficiency programs is constrained by the following problems: insufficient funding; insufficient state support for project financing; distrust of co-owners to the effectiveness of the project; unsatisfactory condition of the apartment building, which requires significant financial costs. The growth rate of the number of condominium applications shows an increase in public confidence in the Program. However, they are not enough to talk about launching large-scale energy modernization of multi-apartment housing. Financial support of local authorities to their residents in the implementation of energy saving measures will contribute to even better results.
\end{abstract}

Key words: energy efficiency, energy saving, effectiveness of apartment building management, Warm Credits Program, cost of energy resources, EnergyHouse.

JEL Classification: R20, R29, M19, L99

\section{Introduction}

The analysis of the effectiveness of apartment building management should include all aspects of this process, however, due to limited statistical and other information on apartment building management across the country as a whole, rather than by individual cities or regions, it seems appropriate to analyze the following aspects of management process:

1. Organizational efficiency of apartment building management.

2. The effectiveness of the system of legal regulation of apartment buildings in Ukraine.

Corresponding author:

${ }^{1}$ SHEI «Ukrainian State University of Chemical Technology», Ukraine.

E-mail: spkiris@gmail.com

ORCID: https://orcid.org/0000-0001-6905-9682
3. The effectiveness of involving co-owners of apartment buildings in management.

4. The effectiveness of communications in the management of apartment buildings.

5. Energy efficiency.

Issues of energy efficiency of apartment buildings have recently come to the fore, because the achievement of its high level gives co-owners of apartment buildings the following advantages:

- reduction of heating costs;

- improving the condition of common property;

- the possibility of further modernization of management processes;

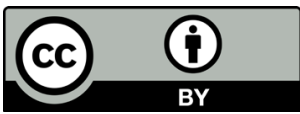

This is an Open Access article, distributed under the terms of the Creative Commons Attribution CC BY 4.0 
- improving the quality of life (ensuring proper heating and water heating), etc.

\section{Researches of the level of interest in the energy efficiency}

Increasing the level of energy efficiency of apartment buildings contributes to improving the payment discipline of co-owners, modernization of housing. Thus, in January 2020, the Ministry of Development of Communities and Territories of Ukraine conducted an analysis of the results of a survey conducted among the heads of condominiums to examine the level of their interest in implementing energy efficiency measures. The conducted researches, first of all, were carried out to determine public opinion on the reform of energy efficiency of apartment buildings, the level of their involvement and attitude to possible benefits.

The results of the researches were as follows (Figure 1).

Also, among the respondents, the largest share is occupied by those apartment buildings that have installed energy-saving lamps in the house, and the smallest share - those houses that have reduced the heating area (Figure 2).

In our opinion, such results of insufficient introduction of energy-saving technologies are caused by the following:

Association of co-owners of an apartment building from Dnipropetrovsk and Zaporizhia oblasts showed the greatest efficiency in this survey, and although the data obtained and presented in the study cannot be used to analyze the energy efficiency of all apartment buildings in Ukraine, they give a general idea of the state of energy efficient technologies in apartment buildings.

\section{An energy efficiency and energy audit}

Currently, the terms "energy efficiency" and "energy saving" are extremely popular in Ukraine, due to the following:

- increasing the cost of energy resources;

- limited financial capacity of vulnerable groups to pay for services;

- deterioration of the state housing stock and heat loss by many apartment buildings in the process of increasing their service life.

Therefore, in Ukraine, an energy audit has been introduced for apartment buildings, which allows for a thorough assessment of this problem and the identification of optimal ways to save energy resources by apartment buildings. Energy audit is a special examination of residential buildings or enterprises, conducted by specialized specialists in energy certification of buildings to determine their technical condition and energy efficiency.

The Law of Ukraine "On Energy Conservation" established that the energy audit is "determining the efficiency of fuel and energy resources and developing recommendations for its improvement".

Based on the interpretation of the provisions and norms of this Law, we note that energy audits are conducted to assess the efficiency of use (in our case - apartment buildings) of energy resources and the development of economically viable measures to reduce their consumption, namely to identify areas of energy efficiency.

This assessment provides an opportunity to determine the level of fuel efficiency of homes and identify the most vulnerable places where excessive energy loss occurs. Based on the results obtained,

\begin{abstract}
implemented measures aimed at reducing electricity consumption
\end{abstract}

have energy meters

installed energy-saving lamps

definitely ready to take loans to implement energy saving in the house

rather ready to take loans to implement energy saving in the house

energy modernization measures will reduce energy costs

Figure 1. The main results of the researching

Source: built by the author

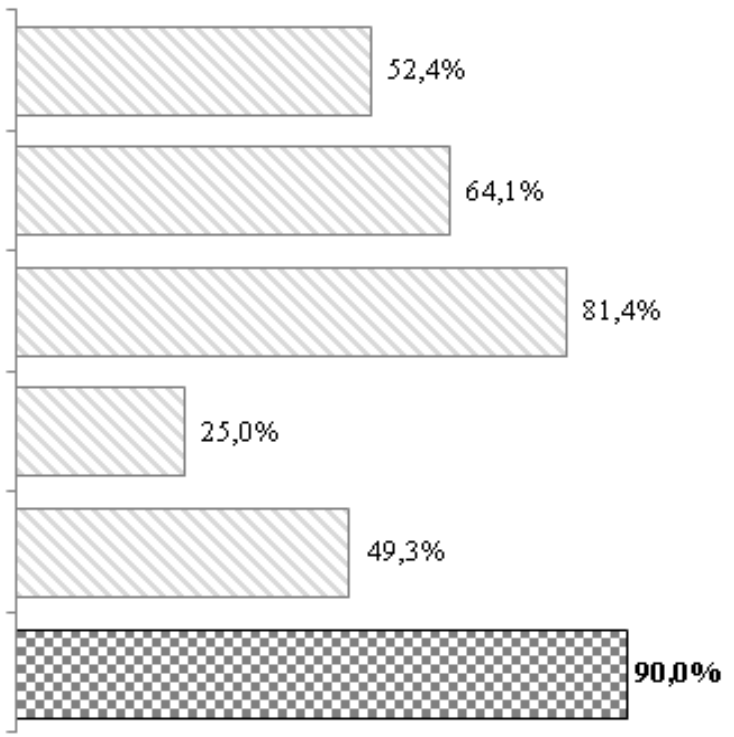




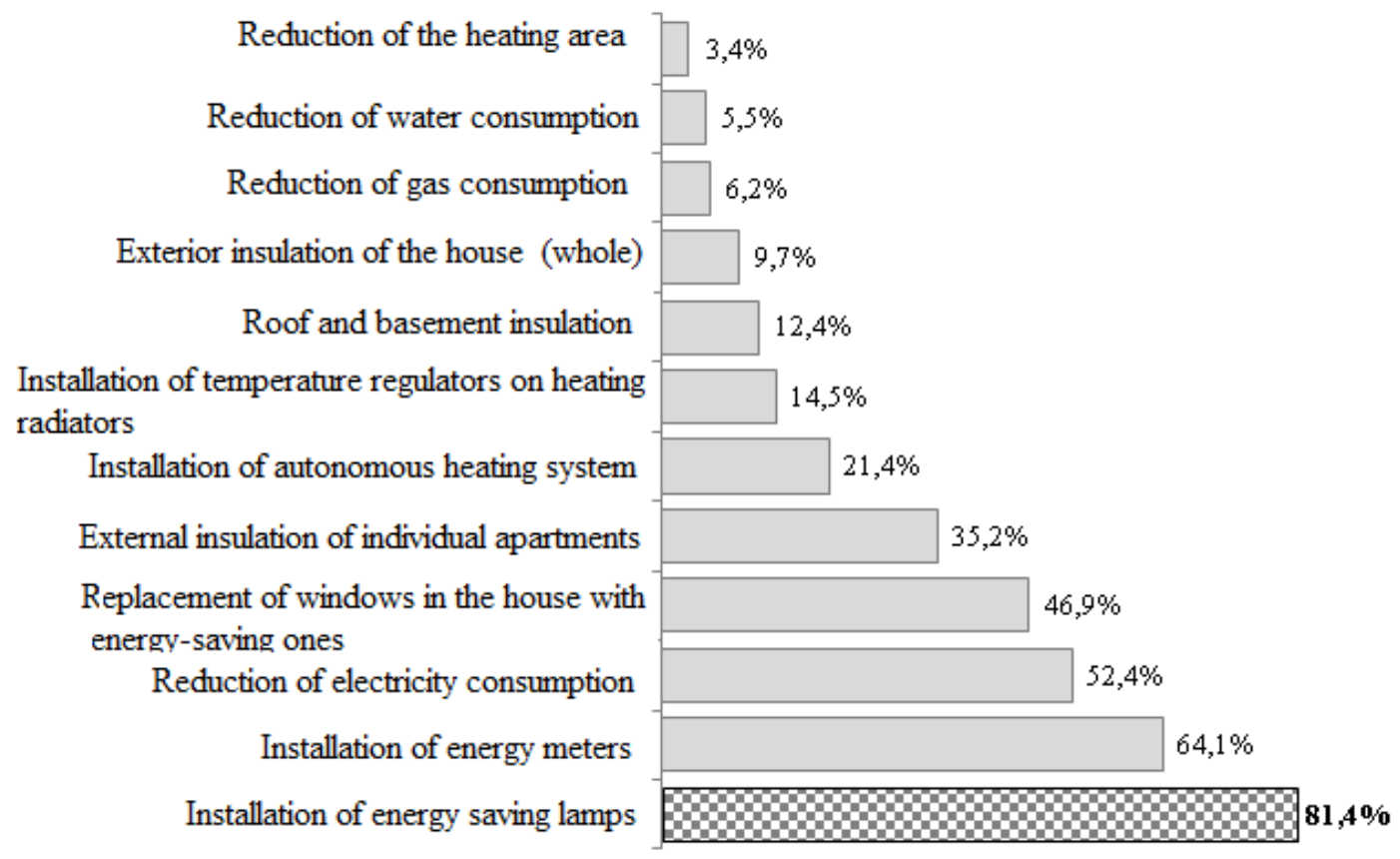

Figure 2. Use of energy efficiency practices in apartment buildings in Ukraine

audit specialists develop appropriate energy saving measures, as well as programs and recommendations for apartment buildings that need to be implemented to increase energy efficiency and reduce energy losses in the house. In addition, the priorities for the implementation of the recommended measures are determined, taking into account the current level of funding for these measures. The energy audit process provides an opportunity to obtain recommendations for the implementation of energy management systems, which can be provided as an option.

Thus, the development of energy efficiency programs of an apartment building is carried out not only taking into account the necessary priority measures, but also based on the financial capacity of the co-owners of the apartment building. We believe that taking into account financial capacity is one of the determining factors in the implementation of energy saving programs, because, according to the researches, to participate in energy modernization condominiums can spend a maximum of $20.8 \%$ of the energy efficiency project (Figure 3).

Such indicators of the ability to finance energy projects by co-owners of apartment buildings are due to the fact that the main share of apartments in an apartment building is ready to finance an amount not exceeding UAH 500 per month (Figure 4).

An expanded list of domestic energy auditors has been opened for use as part of the interactive energy auditors' map developed by GIZ and the Energy Efficiency Fund. The map contained contacts of specialists on energy efficiency certification of buildings, regions of their activity, information on work experience and other information. The resource provided opportunities to find experienced energy auditors for work in apartment buildings.

It should be noted that the cost of energy audit works and reimbursement of their cost from local budgets are important enough to make a decision. In particular, among the surveyed condominiums, $48.6 \%$ determined that the percentage of reimbursement of the cost of the energy efficiency program is important for them (Figure 5).

\section{State support for energy efficiency}

It is also worth noting that state support for the introduction of energy efficiency in the management of apartment buildings includes the following: State support for energy efficiency projects (Warm Credits Program). The program of state support for energy efficiency measures in apartment buildings is implemented under the State Targeted Economic Program for Energy Efficiency and Development of Energy Production from Renewable Energy Sources and Alternative Fuels for 2010-2021, (Warm Credits Program), which provides for encouraging co-owners of apartment buildings and housing cooperatives to introduce energy efficiency measures by reimbursing part of the cost of loans raised for the purchase of energy efficient equipment and materials.

According to the Procedure for the use of funds provided in the state budget for the implementation of measures for the efficient use of energy resources and energy conservation, the mechanism for implementing 
Vol. 2 No. 3, 2021

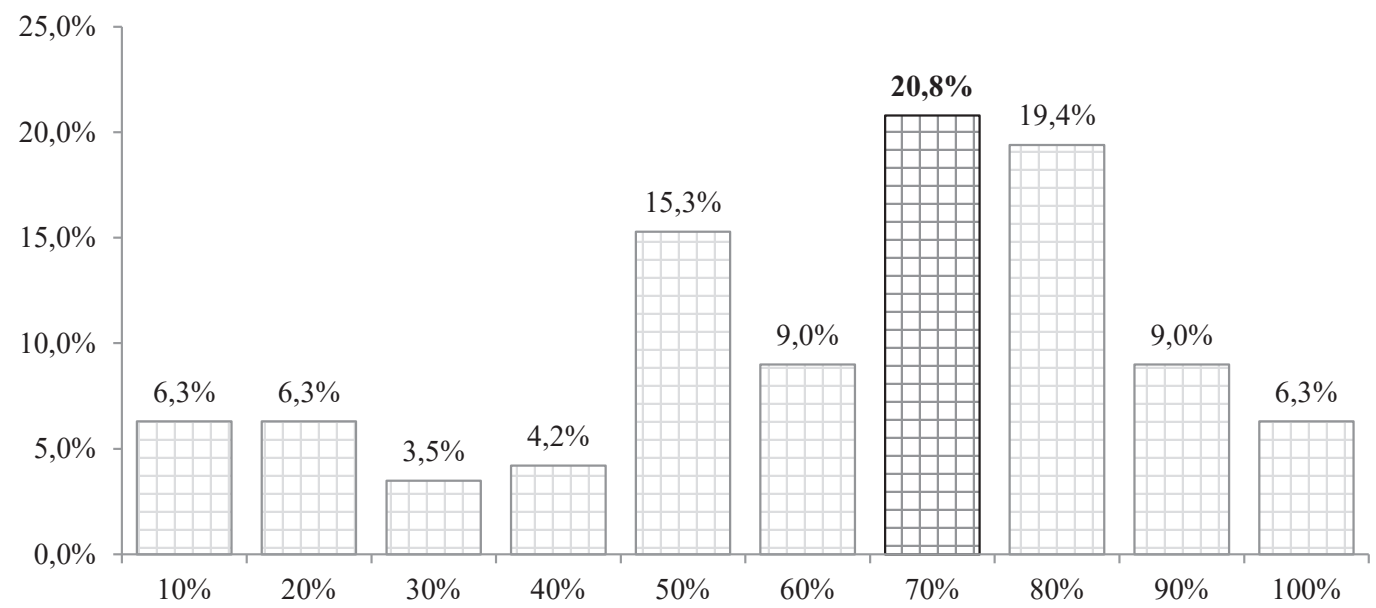

Figure 3. Minimum percentage of compensation that is ready to finance condominiums of Ukraine to participate in energy modernization

Source: constructed by the author

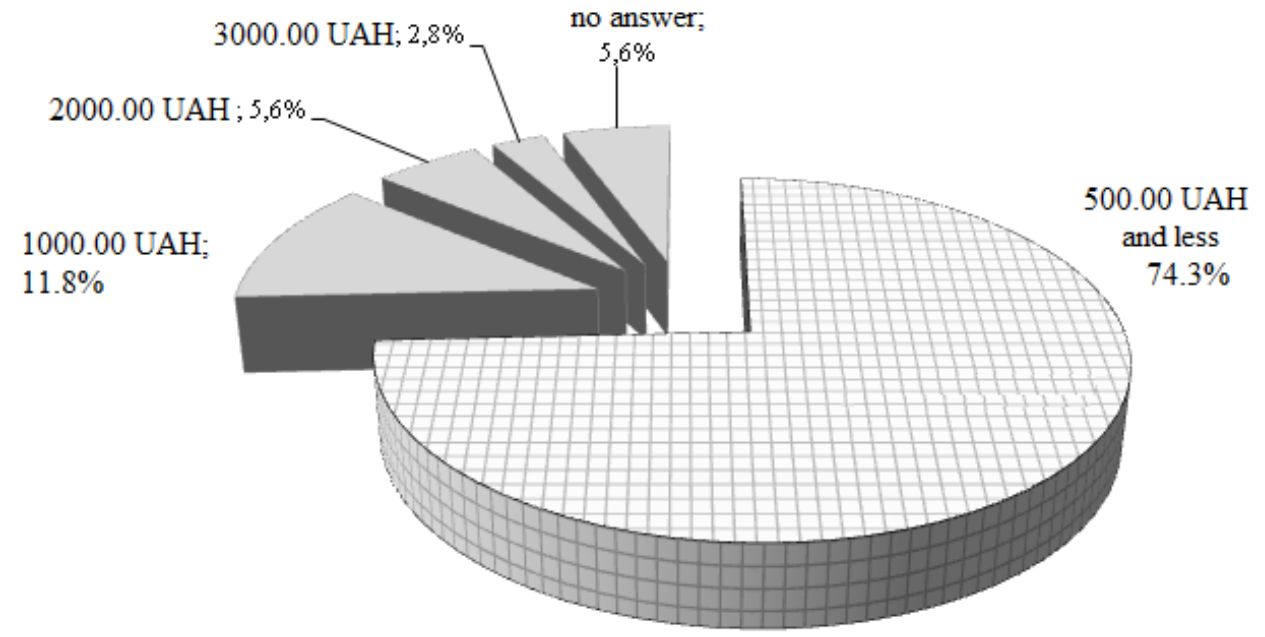

Figure 4. The cost of 1 apartment for the implementation of the energy modernization project (project duration - 6 months)

Source: constructed by the author

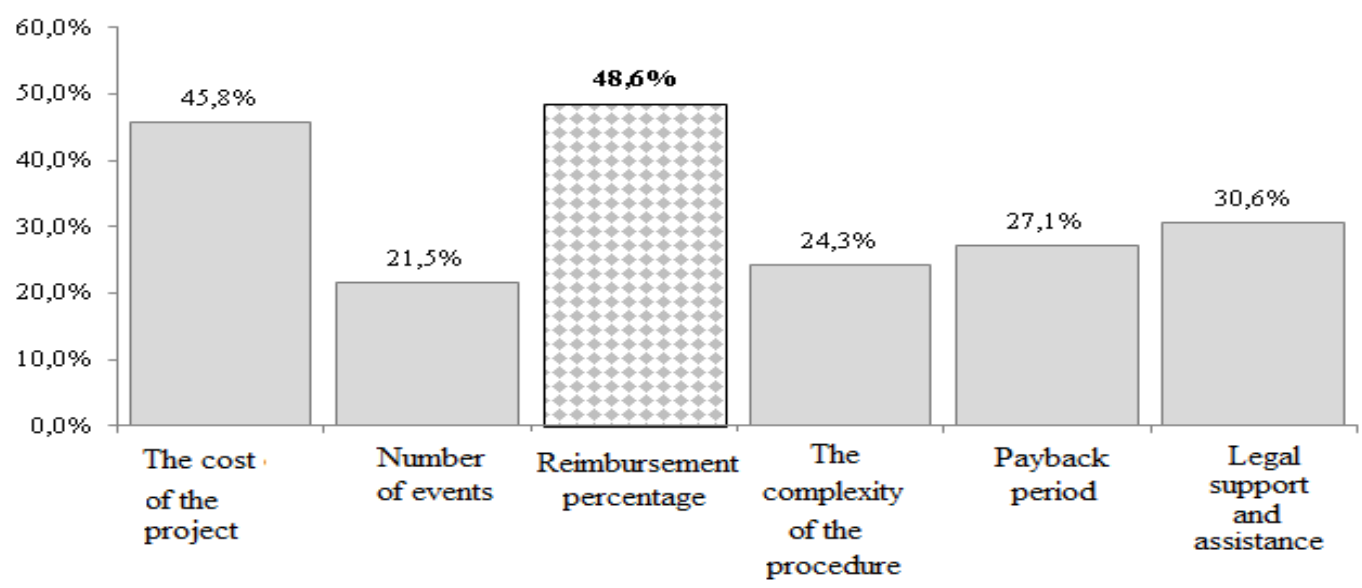

Figure 5. The most important characteristics of condominiums' participation in energy efficiency programs Source: constructed by the author 
the Program and the mechanism for determining its responsible executors was determined. In 2019, according to the resolution of the Cabinet of Ministers of Ukraine "Some issues of optimizing the system of central executive bodies" to optimize the system of central executive bodies is the process of reorganization of individual central executive bodies, primarily the Ministry of Community of Energy and Environmental Protection of Ukraine (Ministry of Energy of Ukraine). In turn, there have also been changes in the powers and tasks of the relevant ministries. Today, according to this Procedure, the responsible executor of the program "warm loans" - the State Agency for Energy Efficiency and Energy Saving of Ukraine, and the main administrator of budget funds - the Ministry of Energy of Ukraine. We also note that in 2020, according to the resolution of the Cabinet of Ministers of Ukraine "On amendments to the resolutions of the Cabinet of Ministers of Ukraine from 01.03.2010 № 243 and from 17.10.2011 №1056" amendments were made to the Procedure and Program, which provided funding for account of the state budget in the amount of UAH 150 million. and the direction of the Program in 2021, which aims to repay part of the amount of loans in the following areas: incentives for co-owners of apartment buildings; Encouraging citizens to purchase boilers using any type of fuel and energy (the exception is natural gas and electricity).

For 2021, the Program and the Procedure did not provide for the reimbursement of part of the amounts of loans raised to stimulate condominiums and housing cooperatives to implement energy efficiency measures in apartment buildings. Development of local programs to support the development of apartment building management, which implement energy efficiency measures.

It should be noted that on September 2, 2021, 43 communities approved their own programs to support condominiums in order to reduce the financial burden on co-owners in the process of implementing energy efficient projects in apartment buildings. Note that the 16 local programs that were approved earlier do not need to be changed or adapted, and 34 are under development. Thus, the latest programs analyzed by the Fund were approved by local governments in the following cities:

- Bar; Veselivska UTC; Energodar; Krasnopil UTC; Mukachevo;

- Netishyn; Butts; Pereyaslav; Uzhhorod; Chortkiv.

\section{Conclusions}

The purpose of the programs is to stimulate the creation of condominiums and provide them with financial support by partially reimbursing the costs of loans taken to implement energy saving measures in apartment buildings. Analyzing the results of the implementation of the «EnergyHouse» Program in Ukraine, we note that in Ukraine, 53 condominiums participating in the Program have fully or partially carried out construction and installation work in buildings.

Thus, at the end of 2020, some co-owners of apartment buildings estimated the savings in utility bills through the introduction of energy saving measures. It was planned that by the end of 2021 the first projects in 11 regoins should be fully implemented, and this should be a significant impetus and a worthy example for other apartment buildings that have not yet decided whether to participate in this Program or not. Yulia Holovatyuk-Unguryanu, director of the Energy Efficiency Fund, notes that "the growth rate of the number of condominium applications shows an increase in public confidence in the Program. However, they are not enough to talk about launching large-scale energy modernization of multi-apartment housing. Financial support of local authorities to their residents in the implementation of energy saving measures will contribute to even better results. We agree with the expert that the large-scale involvement of apartment buildings in the implementation of energy efficiency programs is constrained by the following problems:

- insufficient funding;

- insufficient state support for project financing;

- distrust of co-owners to the effectiveness of the project;

- unsatisfactory condition of the apartment building, which requires significant financial costs.

In total, from September 2019 to the second quarter of 2021, 151 memoranda of cooperation were signed between the Energy Efficiency Fund and the MHI. In 2021 it is planned and partially signed Memoranda with the cities of the following regions of Ukraine: Zaporizhia; Kherson; Sumy; Dnipropetrovsk; Transcarpathian; Cherkasy; Kirovograd; Mykolayivska; Odessa; Kyivska; Rivne; Lviv; Zhytomyr; Volyn; Ivano-Frankivsk; Poltava.

The Foundation in 2021 also sent letters of invitation to more than 250 cities and communities.

\section{References:}

Energy Efficiency Fund (2021). Enerhodim [Energy house]. Retrieved September 16, 2021 from: https:// eefund.org.ua/ponad-40-gromad-zatverdili-miscevi-programi-pidtrimki-osbb-scho-vprovadzhuyutenergoefektivni

Law of Ukraine of July 01,1994 № 74/94-VR (1994). Pro enerhozberezhennia On energy saving]. Retrieved September 02, 2021 from: https://zakon.rada.gov.ua/laws/show/74/94-\%D0\%B2\%D1\%80\#Text 
Ministry of Development of Communities and Territories of Ukraine (2020). Enerhoaudyt - tse diahnoz dlia vashoho budynku abo pidpryiemstva [Energy audit is a diagnosis for your home or business]. Retrieved September 02, 2021 from: https://www.minregion.gov.ua/press/news/za-otsinkoyu-minregionu-ponad-3700osbb-gotovi-vzyati-uchast-u-programi-energodim/

Ministry of Development of Communities and Territories of Ukraine (2020). Rezultaty opytuvannia OSBB shchodo vprovadzhennia enerhoefektyvnykh zakhodiv [Results of the survey of condominiums on the implementation of energy efficiency measures]. Retrieved September 02, 2021 from: https://www.minregion.gov.ua/press/news/energoaudyt-cze-diagnoz-dlya-vashogo-budynku-abo-pidpryyemstva/ Ministry of Development of Communities and Territories of Ukraine (2021). Derzhavna pidtrymka enerhoefektyvnykh zakhodiv v ramkakh Prohramy «Teplykh kredytiv» u 2021 rotsi [State support for energy efficiency measures under the Warm Credits Program in 2021]. Retrieved September 02, 2021 from: https://cutt.ly/xRkbUtL

Postanova Kabinetu Ministriv Ukrayiny (2020). Pro zatverdzhennya Derzhavnoyi cilovoyi ekonomichnoyi programy energoefektyvnosti i rozvytku sfery vyrobnycztva energonosiyiv z vidnovlyuvanyx dzherel energiyi ta alternatyvnyx vydiv palyva na 2010-2021 roky: vid 01.03.2010 № 243 [On approval of the State Targeted Economic Program for Energy Efficiency and Development of Energy Production from Renewable Energy Sources and Alternative Fuels for 2010-2021: Resolution of the Cabinet of Ministers of Ukraine of March 1, 2010 № 243 ]. Retrieved September 02, 2021 from: https://zakon.rada.gov.ua/laws/show/243-2010-\%D0\%BF\#Text

Postanova Kabinetu Ministriv Ukrayiny (2019). Deyaki pytannya optymizaciyi systemy centralnyx organiv vykonavchoyi vlady vid 02.09.2019 № 829 [Some issues of optimization of the system of central executive bodies: Resolution of the Cabinet of Ministers of Ukraine dated 02.09.2019 № 829]. Retrieved September 02, 2021 from: https://zakon.rada.gov.ua/laws/show/829-2019-\%D0\%BF\#Text

Postanova Kabinetu Ministriv Ukrayiny (2018). Pro vnesennya zmin do postanov Kabinetu Ministriv Ukrayiny vid 01.03.2010 № 243 i vid 17.10.2011 №1056, vid 14.03.2018 № 158 [On amendments to the resolutions of the Cabinet of Ministers of Ukraine dated 01.03.2010 № 243 and dated 17.10.2011 №1056: Resolution of the Cabinet of Ministers of Ukraine dated 14.03.2018 № 158]. Retrieved September 02, 2021 from: https://zakon.rada.gov.ua/ laws/show/158-2018-\%D0\%BF\#Text 